\title{
Attitude Of Religious Class Towards Contemporary Female Higher Education
}

\author{
Hafiz M. Inamullah, IER, University of Peshawar, Pakistan \\ Muhammad. Sarwar, University of Sarghoda, Pakistan \\ Naeemullah Khan, Education Department, Punjab, Pakistan \\ Hifazatulla, Islamia College, Peshawar, Pakistan \\ M. Naseeruddin, IER, Kohat University, Pakistan \\ Ishtiaq Hussain, IER, Kohat Univeristy, Pakistan
}

\begin{abstract}
The study aimed at exploring the attitude of religious class towards Contemporary female higher education. The population for the study was the religious class of Kohat, Karak and Dera Ismail Khan of Northwest Frontier Province (NWFP) of Pakistan. Fifty individuals of each category were selected randomly as a sample of the study. Thus the sample consisted of 200 religious individuals.
\end{abstract}

Keywords: Religious class; NWFP; Pakistan; Attitudes; female Higher Education

\section{INTRODUCTION}

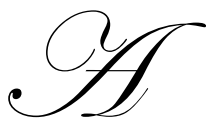

ttitude is the predisposition or tendency to react specifically towards an object, situation or value, usually accompanied by feelings and emotions. Some writers differentiate a verbal attitude from behavioral attitude; attitude cannot be directly observed but must be inferred from overt behavior, both verbal and non verbal(Good, 1959).

Islam gives the right of education to the female gender. The Holy Prophet (Peace be upon Him) commands that acquiring knowledge is obligatory for every man and woman. When both men and women have to face accountability on the Day of Judgment on equal footing, justice demands that none of them should be deprived of knowledge (Ali, 1987).

The importance of women's role in the process of development was recognized long ago. Women have economic, political and social roles to play. Keeping in view the importance of female education, it is believed that major cause of lagging behind in general, in economic and social progress, in most of the developing countries, including Pakistan is the absence of a higher percentage of educated and technically qualified women (Ahmad, 1984).

It is an economic fallacy to suppose that the female are not suitable for economic platform. Women can play an important role in this field and can provide surety for prosperity (Robert, 1976). There can be no doubt that the women of Pakistan are striving to play their part in raising the status of themselves, their families and their nation. Women have already won for themselves an enviable reputation at the highest level of our national life as well as in international circles. We are confident from the spirit which the women of Pakistan have shown in such achievements as those of the All Pakistan Women's Association that they can assume roles of great importance in the consolidation and development of the country if their dynamism and dedication can be nurtured and their efforts guided into those channels where they can be of the greatest service (Govt. of Pakistan, 1959).

According to the economic survey 1997-98, the improvement of female education, innovative approaches both in the formal and informal sectors had been made and given due emphasis at every level of education. The increased access of female gender to general and vocational education through a wide spread of educational facility, 
use of mix of informal and distance education modes based on a new education technology, expansion of nongovernmental sector through financial incentives and innovative campaigns through print and broadcast media, among others, are some of the steps taken by the government for the improvement of female education. (Govt. of Pakistan, 1998).

Pakistan is a developing country. It is quite clear that without imparting education to the female, progress of the society will be very difficult. North West Frontier Province includes tribal areas of Khyber Agency, Malakand Agency, Mohmand Agency, Kurram Agency, Orakzai Agency, North Waziristan and South Waziristan Agency. Almost $90 \%$ of the females with secondary education have very limited access to higher education. There are social, economic, geographic, tribal and pakhtoon culture, war against terrorism and other reasons for their limited access to higher education. However, importance of female education is never denied in the history. Therefore it seems appropriate to study the attitude of religious class towards contemporary female education. This religious class includes Imams and Khateebs, Administrators of Seminaries (Deeni Madaris), Religious Scholars and Religious Politicians.

In the light of the above discussion the study sought to understand the attitude of religious class towards contemporary female higher education in NWFP. The objectives of the study were to explore attitude of administrators of Seminaries (Deeni Madaris) towards contemporary female higher education, to know the attitude of Prayer leaders (Imams khateebs) of mosques towards contemporary female higher education, to investigate the attitude of religious scholars towards contemporary female higher education and to assess the attitude of religious politicians towards contemporary female higher education.

\section{POPULATION AND SAMPLE}

The population of the study comprised of the religious class of District Kohat, District Karak and District Dera Ismail Khan of N.W.F.P of Pakistan.

Random sampling technique was used to select the sample from each of the following strata: Imams and Khateebs, Administrators of Deeni Madaris, Religious Scholars and religious politicionsFifty Religious individuals from each category were selected randomly. Thus the total number of respondents were 200. The detail of the selected individuals is as follows:

Keeping in view the real world constraints, the study was limited only to the districts of Kohat, Karak and Dera Ismail Khan. The population taken as a sample of the study includes Imams and Khateebs, Administrators of Deeni Madaris, Religious Scholars and religious politicians. Other religious minded people were not included in the study. The study is restricted only to the religious class of Muslims. Other religions are not included in the study. Religious politicians include counsellers, Tehsil Nazims, District Nazims MNAs and MPAs of the selected area.

\section{INSTRUMENTATION}

For the collection of data a questionnaire containing 50 items was developed using five-point Likert scale for Imams and khateebs, religious politicians, administrators of Deeni Madaris and Religious scholars after going through related literature, articles, newspapers and other studies. Questions were translated into Urdu language for the convenience of the respondents

\section{DATA COLLECTION}

The researchers collected data through his personal visits in the month of May 2007 to Seminaries (Deeni Madaris), Mosques, homes of Religious politicians and Scholars in the above mentioned districts. It was observed that their attitude towards the research was very cooperative. The questionnaire was distributed to the sampled individuals. The questionnaire was filled in the presence of the researcher. In order to get the required information the researcher had a glance over the questionnaire after receiving it back from the respondent. A close observation was made at the time of filling the questionnaire to get the minute details. In the light of information received through the questionnaires, results have been drawn. 


\section{ANALYSIS OF DATA}

Data collected through above mentioned instruments was tabulated, analyzed and interpreted category wise as Imams and Khateebs, administrators of Deeni Madaris, Religious scholars and religious politicians. To analyse the data chi square was used.

For statistical treatment Chi square was applied using the following formula:

$$
\begin{array}{ll}
\text { fo } & =\text { Frequency Observed } \\
\text { fe } & =\text { Frequency Expected } \\
\text { df } \quad & =\text { Degree of freedom } \\
\text { P } \quad & =\text { Probability of exceeding the tabulated value of } X^{2} \\
& =\text { fo }-\mathrm{fe} \\
& =(\text { fo }-\mathrm{fe})^{2} \\
& =(\text { fo }-\mathrm{fe})^{2} \mathrm{fe} \\
X^{2} & =\sum(\mathrm{fo}-\mathrm{fe})^{2} / \mathrm{fe} \quad \text { (Fogiel, 1985) }
\end{array}
$$

On the basis of the analysis and interpretation of data, conclusions were drawn and recommendations were made. (All tables available upon request from authors)

\section{DISCUSSION}

Education is essential for every member of the society. The process of education is from cradle to grave. The secret of survival of nations lies in education. The nation which lags behind in the field of education dies soon. Pakistan is a developing country and it has a dire need for educating the individuals irrespective of the economic and gender differences for rapid progress. At this time, Pakistan is passing through a very critical situation due to extremism and terrorism and the western world blames Pakistan, especially NWFP, for extremism on the basis of religious extremism. But the ideology of Pakistan is based on two nation theory and two nation theory is based on Islamic principles. As far as Islam is concerned, it does not forbid to seek knowledge rather it insists upon learning. Islam invites the people to ponder and concentrate on the creation of the universe. It develops the attitude of its followers to come forward for enhancement of knowledge.

The ultimate aim of the study was to examine the attitude of religious class towards contemporary female higher education in N.W.F.P. The religious class always leads the nation according to the teachings of Islam but it has been blamed for negative attitude towards contemporary female higher education.

The results of the study revealed that higher education is the right of women. Because women form $52 \%$ of our society, closing the doors of higher education to the female gender results in the deterioration of the nation as well as the country. Maududi (1995) also supported this idea and viewed that women should get all types of education while remaining within the limits prescribed by Islam.

The majority of the religious class was of the opinion that females can play a vital role in economic development of the country by getting higher education according to the norms and values of Islamic society, for example, Hazrat Khadija (R.A) was the most economically sound female in the early history of Islam. Katani(1991) in his book "Ehd-e-Nabvi ka Islami Tamaddun" states that Hazrat Zenab Bint-e-Hajash(R.A) was expert in manual work. She was adept in shoe making and she spent all her earning in the way of Allah. The main objective of higher education is the social and economic growth of the society and the female higher education helps a lot in this 
connection. Anis Ahmad (1984) supported this idea by saying that the major cause of lagging behind in economic and social progress is the absence of educated and technically qualified women.

The study results found that educated women perform their duties better than other women of the society. As the educated women have lot of options before them and it is very easy for them to find a desirable solution of a problem which the other women of the society cannot do as the history of Islam records that Hazrat Aaisha (R.A), the second wife of Holy Prophet (Peace be upon Him), was the most highly educated woman among all male and female of the time. Zakaria (1979) supported the view and stated that many eminent Scholars of the time came to Hazrat Aaisha (R.A) seeking knowledge about Islamic Jurisprudence. He further added that with the help of Hazrat Aaisha (R.A) a solution was found to each and every problem in the field of jurisprudence. World Action Plan (1990) supported this idea which states that education empowers women to exercise their rights and responsibilities as a citizen of the society and enables them to make efficient choices.

Majority in the religious class was of the opinion that highly educated women behave fairly well with her husband and with other members of the family and the higher education based on Islamic ideology imparts and preserves the moral and social values of the Islamic society to the students. During the most important period of infancy and childhood of a person, the female is considered responsible for the intellectual, emotional, social, physical and character development in the families of Muslim society. Saleem (1980) supported this by stating that all the pious people of Islam, who devoted their lives for the welfare of community and religion, were due to the training of their mothers. Khawaja Bakhtiar Kaaki (1235) and khawaja Nizamudin Aolia(1325) accepted the impact of training of their mothers upon them. Sir Syed Ahmad Khan (1817-1898), Maulana Muhammad Ali Jauhar (18731931) and Dr.Muhammad Iqbal (1877-1938) devoted their lives for the welfare of Muslims due to the education and training imparted by their mothers. Telling about the training of the children the Holy Prophet (Peace be upon Him) says that every child is born in original purity; it is his parents who make him a Jew, Christian, or an idol worshipper (Bukhari, 1983). Rao (2000) also supports this idea by saying that the spread of education made women aware of their role in society and the impact of higher education made them realize the importance of improving their rights, privilege and status.

The study results found that the establishment of female universities would play a vital role in female higher education because Islamic culture does not permit co-education at any level, especially, at higher level and in Pakistan, establishing of separate government schools and colleges for female students under separate female administrative authorities is of great importance. Iqbal (1977) supported this idea and noted that Pakistan had inherited one university in 1947, and, in order to provide qualified manpower a large number of colleges, universities and professional institutes were opened. Siddiqui (2004) also supported this idea by viewing that Fatima Jinnah women university and Frontier women universities were established on the demand of parents who preferred to educate their daughters in female institutions. Siddiqui further supported the view that female universities in Indian Sub-continent had helped increase female enrolment in higher education because most of the Muslims are not in favour of co-education system at any level.

The majority of the respondents viewed that highly educated girl is vitally important for grooming and upbringing of children. As the major role of education is the transfer of cultural heritage to the next generation and a highly educated girl can transfer the Islamic values to the next generation very sensibly. Akhter (1986) supports this idea by saying that in the Muslim families rearing of children and their character building is the responsibility of women, so it is necessary for a women to be educated. If the mother is bearing good thoughts and good traits, she may transfer them to her kids. The lap of mother is the first institution of the child. If she is away from ignorance and equipped with knowledge, the coming generation will get good training from this institution and in the future this generation will produce good Muslims. Khanna (2005) further supported this idea and views that women should be given the opportunity to receive education in order to transmit this knowledge to future generations.

The study reveals that most of the people want to educate the female gender up to a higher level without any class difference for the betterment of society. Virk (2003) supported this idea by viewing that women and students from lower income groups have much less participation in higher education which is against the principle of equity and this demands expansion of the base for higher education to give equal access to all the groups of society. 
The study results show that female education helps in increasing family income while taking into consideration the Islamic values and boundaries. World Action Plan (1990) supports this idea by stating that female education has a positive effect on family income.

The study found that it is compulsory for both genders to seek knowledge. This is supported by Shibli (1983) by saying that at times teachers were appointed for education of lords and family girls. Many women got education at their homes and gained knowledge in depth about Quraan and Philosophy. Rashid (1983) further supports this idea and views that our Holy Prophet (PBUH) advises for the education of girls and considers it a virtuous deed.

The study reveals that higher education is not the source of all social evils if it is based on Islamic principles. Moreover it develops character of women. However, sometimes, the environment of higher education institution promotes a negative role to make the women of Muslim society a show piece. Maududi (1995) supports this idea by stating that Islam permits women to gain all sorts of knowledge, which build their character provided they do not exceed the limits, which are prescribed for them in Islam.

The study shows that educated females always abide by the social values because a highly educated woman can understand well the social norms and she can go deeper to understand what has been described as social value. Veer (2004) supports this idea by saying that the education of girls means alteration of gender roles and to understand exercise all human rights.

The study had its flaws as well. The responses might be invalid and unreliable because the age difference of the respondents may influence their views. The responses might be unreliable as with the passage of time the views of the respondents may change. The results were drawn and findings were made by using Chi Squaree. There are other methods of collecting and analyzing the data as well but Likert scale and Chi square were used. The researchers had to go to far flung areas of the selected locality to get the responses. The hilly areas of Karak and Kohat specially created difficulties for collecting the views of religious class about contemporary female higher education. Geopolitical situation of the area was a big hurdle in collecting the data. The religious class was overcautious to respond the questions of the research. The researcher also faced transport problems mostly the local transport stopped soon before sunset and it was very difficult to reach the target point for collecting the data.

\section{CONCLUSIONS}

The following conclusions were drawn from the findings of the study:

1. The respondents viewed that higher education is the right of women and it is helpful in developing their personality and administrative capabilities and they can easily find the solution of the problem by differentiating between right and wrong along with the skillful hand in domestic jobs.

2. A highly educated girl is more social and obedient to her parents and her husband due to the understanding of worldly affairs and that social values, which are part and parcel of higher education. Most of the respondents viewed that the highly educated girl is more intelligent and develops mutual understanding with her husband and other members of the family effectively.

3. Most of the respondents viewed that it is necessary to impart higher education to females without any class difference because the highly educated girl of low income family is a big support in eradication of poverty of that family by using her faculties. The results showed that keeping girls away from higher education is injustice and the whole family would be lagging behind and the consequence is less ratio of development of the society as well as country, for both male and female are part of the same society and society develops more with the education of the both.

4. Separate institutes for female higher education were helpful in enhancing the number of female students for higher studies as the religious class is against the current co-education system due to their adherence with the religion.

5. Higher education is considered as a precious thing and parents could include it as a dowry for their daughters and it is good to equip them with higher education in the current difficult situation for safe future of their children and society. They viewed that highly educated girl maintains her respect in society by 
paying equal attention to the responsibilities of upbringing of children along with the jobs for economic development of the family as well as the country.

\section{AUTHORS INFORMATION}

Dr Hafzi M Inamullah is currently working as assistant professor at The Institute Of Education And Research, University Of Peshawar, Puktoonkhwa, Pakistan.

Dr. Muhammad Sarwar is working as assistant professor at the Department Of Education, University Of Sarghoda.

Dr Naeemullah Khan Education Department, Punjab.

Dr Hifazatullah is working as assistant professor at the Department Islamic Teology, Islmia College Peshawar.

Dr.Naseeruddin, Assistant Professor, Ier, Kohat University.

Dr Ishtiaq Hussain, Assistant Professor, Ier, Kohat University.

\section{REFERENCES}

1. Ahmad, A. 1984. Muslim Women and Higher Education. National Book Foundation, Islamabad. P. 14-17

2. Akhter. N. 1986. Co-education in Islamic view, a research review. Punjab University, Lahore.

3. $\quad$ Ali, Rahmat Chaudhary.1987. Woman's plight. Islamic publications, Lahore. P. 150

4. Fogiel, M. 1985. The Statistics Problem Solver. Research and Education Association, New York.

5. Good, Carter.V.1959. Dictionary of Education. McGraw-Hill Book Company, New York.

6. Government of Pakistan. 1959. The Report Of National Commission On Education, Ministry Of Education, Karachi. P.360.

7. Government of Pakistan. 1998. National Education Policy, "Policy Draft". Islamabad.

8. Iqbal, M. 1977. Women University, a real need. Majla Tanzeem-ul-Taleem. Education Foundation of Pakistan, Lahore.

9. Katani, Abdul Hai. 1991. Ehde Nabvi Ka Islami Tamaddun. Idarah Al-Quran wal Aloom-ul-Islamiah, Karachi.

10. Khanna.P.K.2005. Education in New Millennium. ABD Publishers, Jaipur India.P.328.

11. Maududi, A.A. 1995. Purdah. Islamic Publications (PVT) Limited Lahore. Pakistan. PP. 17, 21, 24, 27, 29 , 33,48

12. Rao, R. k.2000. Women And Education. Kalpaz Publications Delhi. India. PP. 60, 62, 95.

13. Saleem, 1980. Musalmanon ka Nizam-e-Taleem-o-Tarbiat. Islamic Publications, Lahore.

14. Siddiqui, M H. 2004. Technology In Higher Education. APH Publishing Corporation, Darya Gang. New Delhi. PP. 245, 286, 288.

15. Siddiqui, A.H. 1985. Education: An Islamic perspective. University Grants Commission Islamabad.

16. Veer.2004. Modern Education For New Generation. Anmol Publications LTD. New Delhi.

17. Virk, M. Latif. 2003. Higher Education in Pakistan. National Book Foundation Islamabad. P.148.

18. Zakaria, M. 1979. The Stories of Sahabah. Islamic Book service. 